Botar, Oliver A. I. "Forgács, Éva. 2016. Hungarian Art: Confrontation and Revival in the Modern Movement. Los Angeles: DopppelHouse Press." Hungarian Cultural Studies. e-Journal of the American Hungarian Educators

Association, Volume 10 (2017) DOI: 10.5195/ahea.2017.301

\title{
Forgács, Éva. 2016. Hungarian Art: Confrontation and Revival in the Modern Movement. Los Angeles: DopppelHouse Press.
}

\section{Reviewed by Oliver A. I. Botar*, University of Manitoba School of Art, Winnipeg, Canada}

Éva Forgács of the Art College Center in Pasadena, California, is a distinguished historian and critic of Hungarian art, focusing on Modernism and the Avant-garde. The title of her recent book is formulated with great care, and can be understood in at least two ways. At first sight it implies a history of Hungarian Modernism, yet if one ponders it for a moment, it offers, instead, an approach to Hungarian Modernism that is both Hegelian and focused on discontinuity. What we are presented with in this volume is a series of "discrete moments in an epic" as Forgács phrases it in the last paragraph of the Introduction. Beginning with the early twentieth century (mostly Jewish-) Hungarian philosophical fluorescence, and continuing with the classical artistic Avant-garde (both in Hungary and in exile), the Avant-garde of the immediate Post-World-War II "Coalition" period, the Neo-Avant-garde of the 1960s and 1970s, and the end of the Avant-garde in the "New Sensibility" of the 1980s, the volume is completed by a set of appendix-like profiles of what Forgács considers to be "neglected" artists, as some of them are not part of the historical mom(ve)ments that she has chosen to illuminate.

The ambiguity of the book's title belies an ambiguity in the book's genre: is this an anthology of previously published essays or a monograph on the development of Hungarian modern art divided into chapters? While both the second and third paragraphs of Forgács's Introduction begin with the phrases "this selection of essays" and "my essays," respectively, in the fourth paragraph she begins to employ the term "chapters," and states that the "study of any one period of art history reveals art's continuity over a much longer era." In other words, she is proposing a continuity that suggests a unity, even if in diversity. She then points out the discontinuities of Hungarian art history, of the rupture, for example, between the "classical" and "neo" Avant-gardes. However, Forgács offers at least three dialectical correctives to this narrative of rupture between the two: She identifies in the writer and artist-impressario Lajos Kassák and the painter Dezső Korniss actors who embodied continuity; she remarks on the awareness on the part of Neo-Avant-garde artists of their classical Avant-garde roots, and she offers the insight that in East-Central Europe the two Avant-gardes played the same, oppositional roles in their respective periods, thus rendering them, in effect, a single movement.

While Forgács states in her Introduction that the (once again) "essays" were written after her emigration in 1993, the "Bibliography of Original Publications" on page 293 is partial, and as the author herself notes, "significant or whole portions of the essays... have been edited from

*Oliver.Botar@umanitoba.ca

$($ (c) $)$ EY

ULIS D-Sente
New articles in this journal are licensed under a Creative Commons Attribution 4.0 International License.

This journal is published by the University Library System of the University of Pittsburgh as part of its D-Scribe Digital Publishing Program and is cosponsored by the University of Pittsburgh Press 
Botar, Oliver A. I. "Forgács, Éva. 2016. Hungarian Art: Confrontation and Revival in the Modern Movement. Los Angeles: DopppelHouse Press." Hungarian Cultural Studies. e-Journal of the American Hungarian Educators Association, Volume 10 (2017) DOI: 10.5195/ahea.2017.301

[her] previously published articles." So, to restate my question, to what extent are these texts chapters of a monograph, or independent, previously published essays arranged in a particular order? Again, the essays (or chapters - I will refer to them here as "essay-chapters") themselves send mixed messages. At times there are cross-references within them when a sense of continuity is called for. At other moments, there are repetitions of similar material, as in the case of Béla Kondor, about whom Forgács writes in both the Neo-Avant-garde essay-chapter and in her appended text on Kondor and Lajos Vajda. The same could be said for Miklós Erdély and the essay-chapter on the Neo-Avant-garde, and of László Fehér with respect to the essay-chapter on the New Sensibility. And yet, despite these discontinuities and repetitions there is a crystal-clear narrative arc leading from the first essay-chapter, "Enlightenment Versus the 'National Genius'," to the last one before the appendices, "Deconstructing Constructivism in Post-Communist Hungary."

The narrative arc of the book would have benefitted from the inclusion of a chapter on the interwar context that gave rise to two artists, István Farkas and Lajos Vajda, to whom, as mentioned, Forgács devotes short essay-chapters as appendices to the heart of the volume. And this goes particularly for the work of Vajda and his circle, who were the closest thing to a Surrealist movement in interwar Hungary. The fact that Forgács refers repeatedly to Hungarian Surrealism (e.g., 11, 140, 191), and yet her references are unsupported by any substantial texts on her part, just underlines my point, and indicates to me, at least, that Forgács was, consciously or not, aware of this lack but was, for some reason, unable to fill it. As the first scholar of Ernö Kállai's critical oeuvre, Forgács would have been especially well suited to incorporate these two artists, as well as László Mednyánszky for that matter, into an essay-chapter on Kállai's critical activities after his return to Hungary in 1935, since Kállai devoted monographs to all three, and his concept of "Bioromantik" deals insightfully with Surrealist tendencies in Hungarian and other European art. In fact it is my view that all of the appendices on individual artists or artistic pairings could have been incorporated into the earlier essay-chapters, lengthening them to be sure, but also avoiding redundancy in the process.

The tension between the incorporation and the exclusion of material on a given "outsider" into a given synthetic essay-chapter is of course a central dilemma of all art-historical writing. What is interesting here is that, while rendering these tensions apparent in her book, Forgács never addresses them explicitly. And this is also true of the inevitable omissions in her work, to which Forgács refers, e.g., in her discussion in the Introduction of what she does and does not cover regarding the Neo-Avant-garde. No monograph on the history of any artistic tradition can ever include everything and, in any case, what she offers here is - as far as I am aware - the most extensive and most incisive text on the Hungarian Neo-Avant-garde of the 1960s and 1970s to have appeared in English. In short: Forgács seems to want to have written a monograph on the history of the "Avant-garde" or "modern" or "progressive" tradition in Hungarian art (all terms she employs), and yet she seems to resist this goal, clinging to the notion that this is a series of discrete essays. The fact that she would not have been able to cover every topic in the field is immaterial. Her long experience, equipment, approaches, recurrent themes, erudition, judgment and synthetic brilliance would have easily facilitated her achievement of such a goal. Given her career and accomplishments, Forgács has earned the right to author a history of Hungarian Modernism(s). 
Forgács's vast knowledge and her ability to identify and synthesize broad swaths of intellectual and conceptual development becomes evident already in the first essay-chapter of this book, which describes the decades-long effort on the part of Hungarian artists, philosophers, art historians and other intellectuals to find a way to create a culture based in Hungarian traditions that could take its place among the international currents of early twentieth-century Modernism, while extending it into the 1930s and indeed to the efforts of the Neo-Avant-garde of the 1970s, which is pretty well the temporal extent of the book as a whole. This is a synthesis that I have never before encountered, and one that is thrilling to read in English. The cast of characters may have been drawn from a provincial pool, but there is nothing provincial about it. Some are at least somewhat known to Western readers (Georg Lukács, Béla Bartók, Béla Balázs, Zoltán Kodály, Karl Mannheim, Frederick Antal, Arnold Hauser, Ernő Kállai), and many are not (Tivadar Csontváry-Kosztka, Anna Lesznai, Miklós Izsó, Károly Kernstok, Lajos Fülep, Katalin Kemény, Béla Hamvas, Lajos Vajda, Dezső Korniss, Ilona Keserü, Imre Bak, István Nádler, Gyula Pauer). In any event, Forgács makes it evident that despite its marginalization, this is a tradition that is both firmly rooted in the larger European one, and in no way inferior to it. In other words, Forgács's perspective is critical but never patronizing, sympathetic but never parochial. Whether it is German Romanticism or Idealist philosophy, psychoanalysis or the study of mythology, nationalism or internationalism, international currents of artistic, theatrical, literary or musical Modernism, Hungarians - Christians and Jews - were both familiar with and embedded in the larger discourses while they attempted to discover or develop formulae for being-in-the-world as Hungarians and as Europeans. This type of sweep - knowing what to leave out and what to include in order not to be long-winded, so that the reader would not lose the main thread of the argument by being immersed in a flood of detail - is the purview of only the most skilled historians. This initial essay-chapter, then, already gives evidence of this kind of exceptional ability, and it is manifest throughout the book.

While Forgács begins her Introduction by stating that the volume is, "inevitably, autobiographical," dealing first and foremost with the Neo-Avant-garde of the post-1950s period that she personally experienced in Hungary, in fact most of the book deals with the early twentieth century and the "classical" Hungarian Avant-garde of the 1910s to the 1940s - the latter being a field of which she is one of the most important scholars. As mentioned, Forgács claims to have written these essay-chapters after her move to Los Angeles in 1993, a relocation that afforded her a different perspective on the culture she had known before, seeing it both from within and without. This is what renders the book extraordinary: It is written by one who was both a witness and a participant, a Hungarian historian of Hungarian modernism and an American scholar-critic of Hungarian art. This is why she is able to write with such incisive empathy about the fate of those who went into exile. In short, it is these varied and potentially contradictory statuses that afford Forgács both the knowledge and the perspective to achieve what she has achieved. The critical depth and the insight, the analytical and synthetic skills displayed with such brilliance in this volume are, however, entirely her own. They were at play in her writing completed in Hungary before 1993 just as they are here.

The book's brilliance cannot mask the author's putative insecurities and reticence. However, the resulting tensions and discontinuities, indecision and lack of clarity as to what kind of book this actually is, paradoxically, also contribute to its exceptional nature. Perhaps the best way to think of this volume is that Éva Forgács has (re)invented in it a genre of scholarly and 
Botar, Oliver A. I. "Forgács, Éva. 2016. Hungarian Art: Confrontation and Revival in the Modern Movement. Los Angeles: DopppelHouse Press." Hungarian Cultural Studies. e-Journal of the American Hungarian Educators Association, Volume 10 (2017) DOI: 10.5195/ahea.2017.301

critical, yet deeply autobiographical, art historical writing. In other words, this is a book that is (at times) unconsciously frank (if I might coin an oxymoron) concerning her humanity, her Hungarianness, Jewishness and Americanness. All these, combined with her intellect, cultural knowledge and research, analytical and synthetic skills, is what makes Hungarian Art:

Confrontation and Revival in the Modern Movement a text that I was unable to put down; one that will be used by those interested in the field for a long time to come. 